\title{
ASSESSMENT OF A LOW-COST PORTABLE PROPORTIONAL EXHAUST SAMPLING SYSTEM FOR GRAVIMETRIC PARTICULATE MATTER EMISSIONS MEASUREMENT
}

\section{MICHAL VOJTIIŠEK}

Department of Automotive, Combustion Engine and Rail Vehicle Engineering, Faculty of Mechanical Engineering, Czech Technical University in Prague, Technicka 4, 16607 Prague 6, Czech Republic, E-mail: michal.vojtisek@fs.cvut.cz

\section{MARTIN PECHOUT}

Department of Vehicles and Engines, Faculty of Mechanical Engineering, Technical University of Liberec, Studentska 2, 46117 Liberec, Czech Republic, E-mail: martin.pechout@tul.cz

\section{SHRNUTI}

Částice obsažené ve výfukových plynech spalovacích motorů jsou jejich pro lidské zdraví nejvíce škodlivou složkou. Se snižující se celkovou hmotností emitovaných částic se zvyšují nároky na její měření, které vyžaduje plnoprůtočný redicí tunnel nebo proporcionální vzorkovač $s$ reděním části toku s rychlou odezvou. Pro umožnění takových měřní během jízdy vozidla a $v$ méně vybavených laboratořích bylo vytvořeno nízkonákladové zařizení pro proporcionální vzorkování výfukových plynů. Zařizení využivá dvojici regulátorů hmotnostního průtoku, z nichž jeden dodává proměnlivé množství ředicího vzduchu do miniaturního ředicího tunelu, a druhý udržuje konstantní průtok směsi ředicího vzduchu a výfukových plynů přes filtr, na který jsou částice vzorkovány. Výsledky naměřené tímto systémem během dynamických jízdních cyklů jsou, po korekci systematického rozdílu, v rozmezí faktoru dvou od výsledků gravimetrické analýzy vzorků odebraných z klasického plnoprůtočného ředicího tunelu.

KLIČCVÁ SLOVA: SPALOVACI MOTOR, VÝFUKOVÉ EMISE, ČÁSTICE, CELKOVÁ HMOTNOST ČÁSTIC, GRAVIMETRICKÁ METODA, PROPORCIONÁLNI VZORKOVÁNÍ, PEMS, MĚrenÍ ZA PROVOZU, PŘENOSNÉ ZAŘíZENÍ

\section{ABSTRACT}

Particulate matter (PM) is considered to be the most harmful component of internal combustion engine exhaust to human health. At decreasing levels of total PM mass, its measurement is challenging, requiring either a full-flow dilution tunnel or a fast-response, variable dilution ratio sampler. To allow for such measurements on the road and in lesser equipped laboratories, a low-cost proportional sampling system has been developed. The system uses a pair of mass flow controllers, one of which meters filtered air into a heated miniature partial-flow dilution tunnel, and the other one regulates the flow of diluted exhaust through a filter on which PM is sampled. Results obtained with this system during transient tests fall, after corrections for measurement bias, within a factor of two of measurement obtained with a full-flow dilution tunnel.

KEYWORDS: INTERNAL COMBUSTION ENGINE, EXHAUST EMISSIONS, PARTICULATE MATTER, PARTICULATE MASS, GRAVIMETRIC METHOD, PROPORTIONAL SAMPLING, ON-BOARD MEASUREMENT, LOW-COST, PEMS

\section{INTRODUCTION}

As internal combustion engines are one of the principal sources of air pollution in most urban areas, the effects of new fuels on exhaust emissions are of concern. Both compression ignition (diesel) and spark ignition (gasoline) engines emit particles predominantly in the tens of nanometers $(\mathrm{nm})$ range $[1,2]$, which, readily deposit in lungs $[3,4]$. Particles in lower tens of $\mathrm{nm}$ range and smaller can penetrate through cell membranes into the blood, and have a wide and detrimental effect on human health [5]. Proximity to sources of internal combustion engine exhaust has been associated with increased risks of various chronic health problems [6-8]. For these reasons, emissions of particulate matter (PM), both in terms of its regulated quantities (mass, total particle number) and its various unregulated metrics (lung-deposited surface area, 
content of various compounds of concern such as carcinogenic polycyclic aromatic hydrocarbons, metals, 3-nitro-benz[a] benzanthrone, and relative toxicity) need to be considered.

The gravimetric determination of total PM mass as well as advanced chemical analyses and toxicological assays require collection of PM on a suitable filter media. Traditionally, such collection has been facilitated by drawing a sample, at a constant flow, from a constant volume sampler (CVS). This approach has, however, some drawbacks, as with modern, low-emitting engines, the contribution of the background is no longer negligible. CVS systems are also large and expensive, and except for special instrumented trailers, they can rarely be used in real-world settings. For these reasons, partial-flow dilution systems are gaining on popularity; an excellent overview of various approaches is given in the engine emissions legislation, for example, EHK 49. Of these, generally only systems with active control of the flows of the dilution air and the diluted sample are suitable for transient measurements, due to the need to adapt the dilution ratio to the dynamic fluctuations of the exhaust gas flow, so that the instantaneous flow of the raw exhaust through the sampling system is always a constant multiple of the total exhaust flow.

One such system has been designed by the first author at the Czech Technical University as an attempt to add PM measurement capabilities to an older engine test stand. The hardware was fabricated mostly by the second author for use as a portable on-board sampling system during on-road measurements. Later, as transient capabilities were added to the engine test stand [9], software control of mass flow controllers was developed by the first author to improve the transient response of the sampling system. This paper describes the design consideration of the system, and preliminary results of laboratory comparison tests during transient operation of several engines as well as practical experiences with the system.

\section{EXPERIMENTAL}

\section{WORKING PRINCIPLE}

The functional diagram of the system is given in Figure 1 . Dilution air is drawn from the outside through a HEPA filter and is metered by a mass flow controller (MFC) to a miniature dilution tunnel located near the sampling point and connected with the exhaust system with a thermally insulated transfer line. A sample is drawn from the dilution tunnel through a sampling filter (typically a $47 \mathrm{~mm}$ diameter) and is metered by a second MFC. The second MFC operates at a constant flow

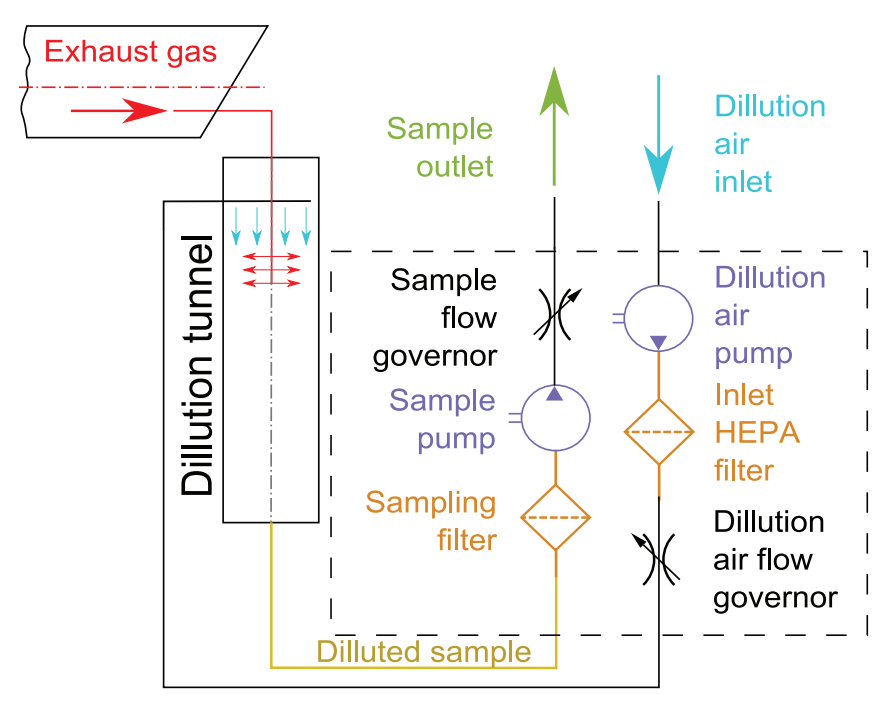

FIGURE 1: Functional schematic of the sampling system OBRÁZEK 1: Schéma vzorkovacího zařízení

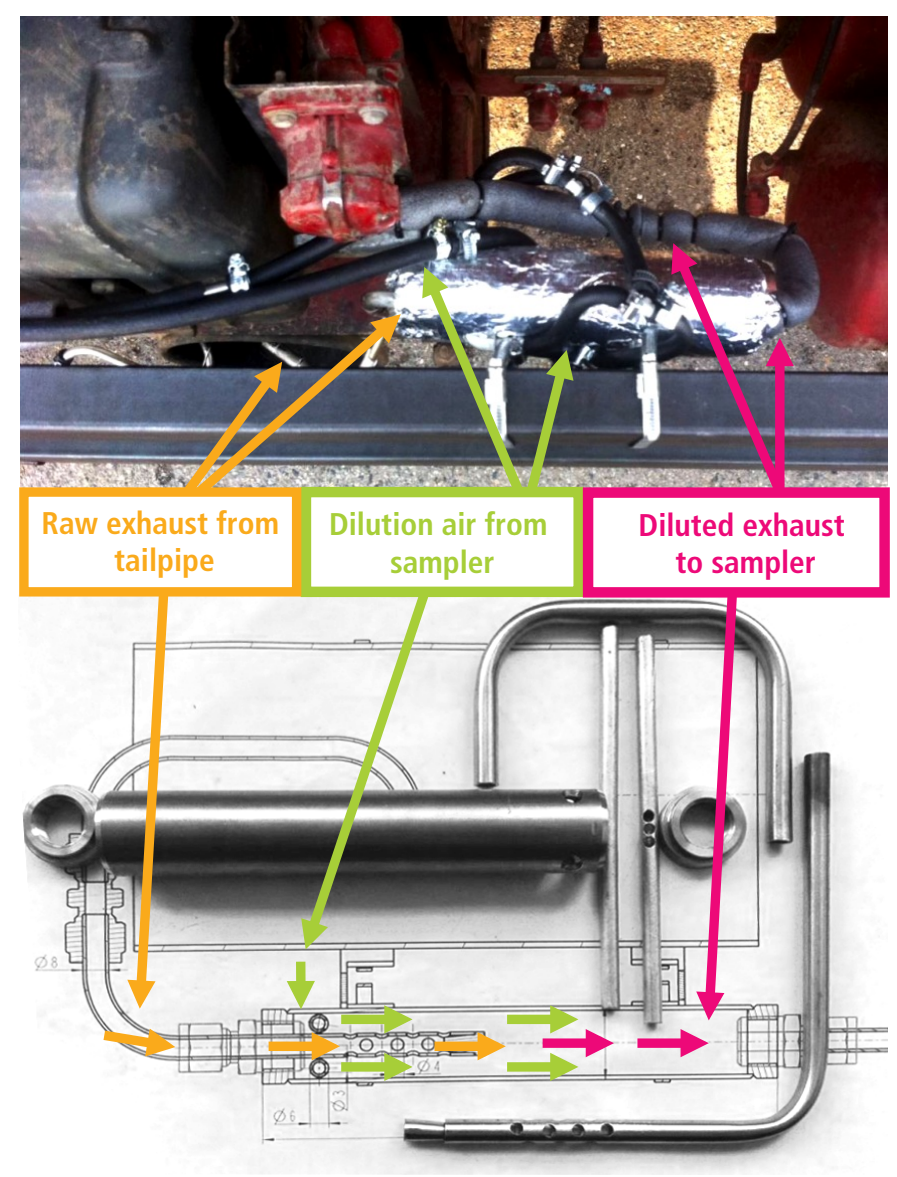

FIGURE 2: Dilution tunnel as installed on Iveco Trakker heavy truck (photo on top), internal parts and drawing (bottom).

OBRÁZEK 2: Ředicí tunnel instalovaný na nákladním voze Iveco Trakker (foto nahoře), vnitřní části a schema ředicího tunelu (dole).

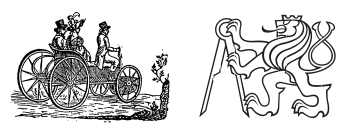


rate, typically in the range of $20-50$ grams of exhaust gas per minute. The flow through the first MFC, providing dilution air, is varied depending on the exhaust gas flow, so that the flow of the raw exhaust, determined as the difference between the flow of the sample and the flow of the dilution air, is proportional to the instantaneous flow of the exhaust from the engine. The practical realization of the latest dilution tunnel, designed by Michal Voráček as his bachelor's thesis work at TU Liberec [10], is shown in Figure 2.

\section{DILUTION RATIO AND DILUTION AIR CONSIDERATION}

The dilution air flow is about $80 \%$ to $90 \%$ of the sample flow at the rated power, providing dilution ratios of $5: 1(80 \%)$ to $10: 1(90 \%)$, increasing to theoretically $100 \%$ of the sample flow when the engine is stopped. In reality, when the engine is not running or the exhaust is not sampled, the dilution flow exceeds the sample flow, ensuring no exhaust entering the sample. The dilution ratio at full power is practically limited on the lower end to around 5:1 to prevent excessive formation of secondary aerosol, and, in more extreme cases, to prevent condensation of water vapor in the sampling line or on the filter. On the upper end, practical limits are imposed by the dilution ratio at lowest exhaust flow, typically at idle. If the maximum exhaust flow is 5-10 times higher than the exhaust flow at idle, at 5:1 dilution ratio at maximum exhaust flow, the dilution ratio at idle is $25: 1$ to $50: 1$. At MFC accuracy of $1 \%$, the accuracy of exhaust flow is around $2 \%$ of the dilution air flow, or, at 50:1 dilution ratio, around $100 \%$ of the exhaust flow.

\section{EXHAUST FLOW DETERMINATION}

As the exhaust gas flow is rather difficult to measure directly due to its high temperature and content of particles, the flow of the dilution air is determined from the intake air flow, which is either measured by a mass flow meter, or, in case of onboard measurement, inferred from engine operating data. The intake air mass flow is obtained from the engine control unit via an EOBD interface, or computed from known engine displacement, known or assumed engine volumetric efficiency at given rpm and load, and engine rpm and intake air pressure and temperature which were obtained from the EOBD interface, using a formula

$\operatorname{MAF}[\mathrm{g} / \mathrm{s}]=0,028967{ }^{*} \mathrm{nvol}^{*} \mathrm{~V}\left[\mathrm{dm}^{3}\right]{ }^{*} \mathrm{rpm}$ * MAP $[\mathrm{kPa}] / \mathrm{IAT}[\mathrm{K}]$

where nvol is engine volumetric efficiency at the given operating point, $\mathrm{V}$ is the engine displacement in liters, MAP is intake manifold absolute pressure in $\mathrm{kPa}$, and IAT is the temperature of the charge in the intake air manifold in Kelvins. This formula is valid for the flow of the air through the engine; any recirculated exhaust must be subtracted. EGR rate can be obtained from the engine control unit, or determined experimentally, for example by measuring air-fuel ratio or concentrations of $\mathrm{CO} 2$ simultaneously in the intake manifold and in the exhaust. This approach has been described in detail in an earlier work [11].

\section{TRANSIENT RESPONSE IMPROVEMENT}

The mass flow controller used have a response time on the order of several seconds. To improve the transient response, without overly compromising the system stability, a fuzzy logic algorithm was implemented to alter the requested flow of dilution air when a transient change in engine intake air flow was detected. For example, during a rapid acceleration of the engine, the control system would decrease the flow of the dilution air so that the flow of the raw exhaust drawn into the diluted sample would increase in proportion to the increase in engine intake air flow. The fuzzy logic algorithm would then exaggerate the demanded change and request a considerably lower dilution air flow, in order to accelerate the transition to the new desired flow.

\section{COMPARISON TESTS AND REFERENCE SYSTEMS}

Several series of comparison tests were conducted on production and prototype diesel engines of various emission levels; where non-production engines were used, no engine information is given.

One series of tests of a prototype engine was run on a modified World Harmonized Transient Cycle (WHTC), which was run according to the prescribed schedule, except that the engine throttle pedal control was set to very high gain, forcing extremely transient operation of the engine. This series was run to evaluate the ability of the experimental system to cope with transients. Reference measurements for these tests were facilited with a commercial proportional sampling system (AVL Smartsampler). All sampling was done on $47 \mathrm{~mm}$ diameter filters of fluorocarbon-coated borosilicate glass fibers (Pall T60A20).

Additional tests were run at the transient heavy engine test bench at the newly constructed laboratories at VTP Roztoky. Reference measurements were taken with a system sampling from the full-flow dilution tunnel. All measurements were done on teflon filters (Pall TX40HI-20WW). World Harmonized Transient Cycle (WHTC), Non-Road Transient Cycle (NRTC) 

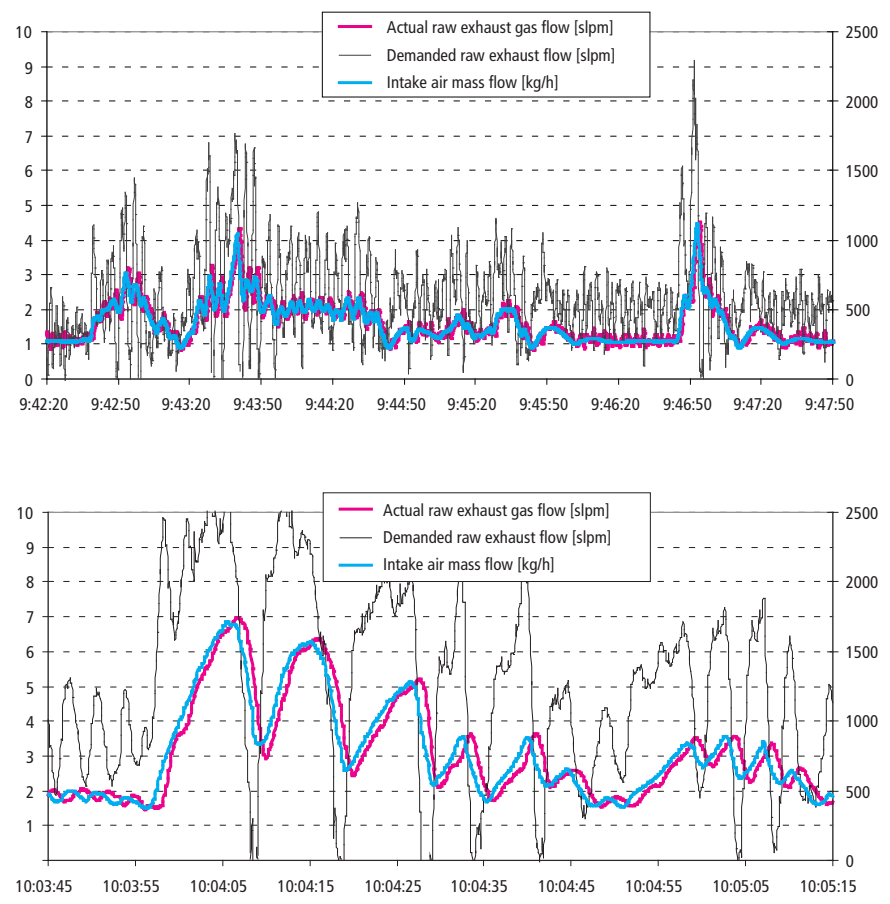

FIGURE 3: Comparison of the actual raw exhaust gas flow into the sampling system with the actual engine intake air flow during three subsequent runs of the WHTC cycle.

OBRÁZEK 3: Porovnání prítoku surových výfukových plynů do vzorkovacího zařizení (tlustá červená čára, levá osa) s tokem nasávaného vzduchu (tenká tmavá čára, pravá osa) a požadavkem na prítok surových výfukových plynů (tenká čára, levá osa) během vybraných částí dynamického cyklu WHTC.

and Engine Transient Cycle (ETC) tests were replicated on an engine equipped with a diesel oxidation catalyst (DOC) and diesel particle filter (DPF), and additional runs of WHTC test were run with no exhaust aftertreatment devices.

Follow-up tests were run on an Iveco Tector engine with no aftertreatment devices during steady-state and transient tests during engine test preparation on various filter media (borosilicate glass fiber and quartz filters). The steady-state tests included extreme modes of operation including extended idle, and full-load after an extended idle where a temporary substantial increase in PM emissions is observed.

In order to evaluate the performance in a moving vehicle, a batch of tests was run on a Czech Railways 854-series passenger rail vehicle powered by a non-road Caterpillar 3412 engine. This vehicle was tested during its regular operation on local and express routes. During these tests, in order to eliminate the effects of flow determination errors, the hypothetical PM mass accumulated on each filter was calculated by multiplying the instantaneous PM mass concentrations determined by a semi-condensing integrating nephelometer by the raw exhaust sample flow reported by the sampling system.

\section{RESULTS}

The alteration of the mass flow controller control signal to achieve a fast response is demonstrated in Figure 3, showing two segments of the WHTC test, a five-minute window on the upper graph and a 90-second highly transient window on the lower graph. From the graphs, it is apparent that the sampling system maintains the flow of the raw exhaust in proportion to the intake air flow, with a delay of approximately one second. A potential drawback is decreased stability at steady-state conditions, where the flow exhibits oscillations, as seen on the upper graph at idle during first ten seconds, period from approximately 9:46:00 to 9:46:40, and last ten seconds. At a nominal sample flow of 24 liters per minute, and dilution air flow rate of $23 \mathrm{lpm}$ at idle to maintain $1 \mathrm{lpm}$ raw exhaust flow into the sample, the fluctuations of approximately several tenths of Ipm represent approximately $1 \%$ of the flow; such oscillations are, however, of lesser concern when averaged over the duration of the steady-state period.

The PM mass for the three transient cycles run with a DPF are shown in Figure 4, span two orders of magnitude. The reference measurement is shown on the horizontal axis, and the measurement by the portable proportional sampling system is shown on the vertical axis. As all transient tests were of 30-minute duration, the results are reported in mass per test.

The aggregate results of the follow-up tests on the Iveco Tector engine are shown in Figure 5. As the duration of these tests spanned from minutes to tens of minutes, the results are reported on a grams per hour basis.

The results of the diesel rail vehicle measurements are shown in Figure 6. As the exhaust flow calculations were excluded from the comparison to exclude related artefacts, the results are reported as mass of PM inferred from the reference laser-based measurement (horizontal axis) and mass of PM determined by gravimetric analysis (vertical axis).

To check for consistency among all described series of test runs, the results obtained with the experimental sampling system were plotted against the respective reference measurements in Figure 7, in mass per transient test or mass per hour. 


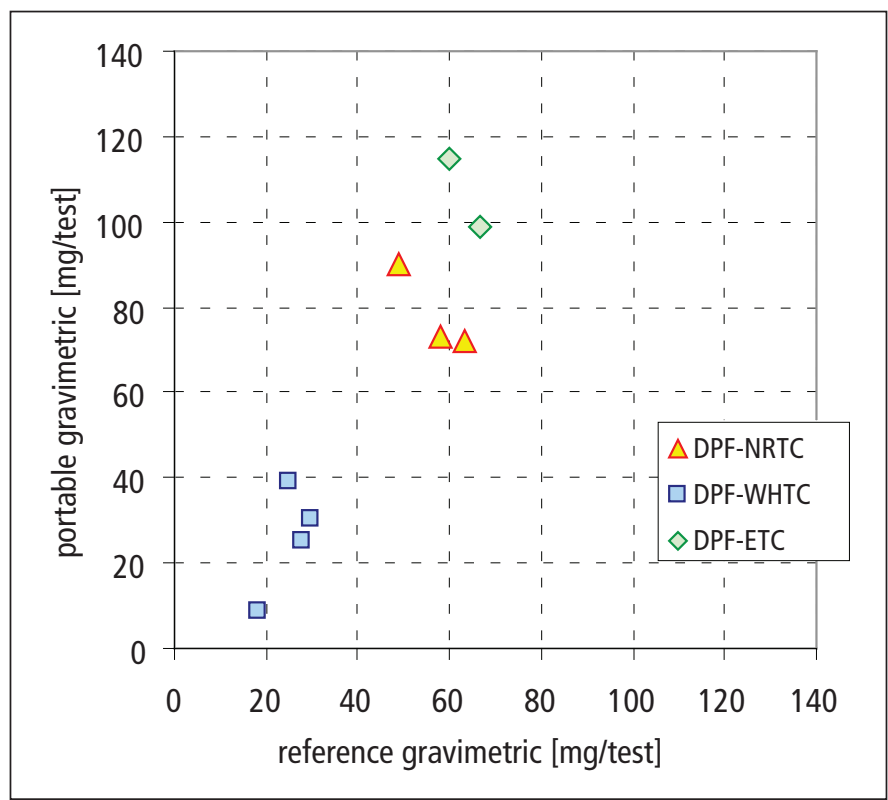

FIGURE 4: Total PM mass measured by portable and reference sampling systems during various transient tests.

OBRÁZEK 4: Hmotnostní emise částic při dynamických zkouškách motoru vybaveného filtrem pevných částic: plnoprůtočný tunnel (vodorovná osa) a experimentální zařízení (svislá osa).

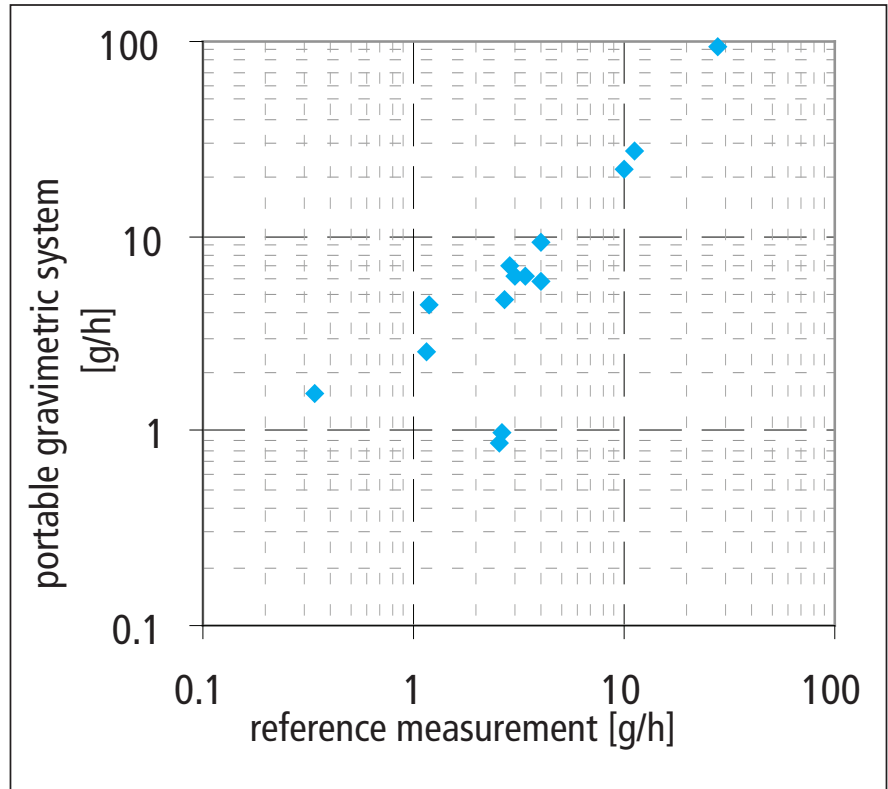

FIGURE 5: Total PM mass measured by portable and reference sampling systems during various transient tests. Iveco Tector engine, no aftertreatment, different filter media.

OBRÁZEK 5: Hmotnostní emise částic prì zkouškách motoru Iveco Tector: plnoprůtočný tunnel (vodorovná osa) a experimentální zařizení (svislá osa).

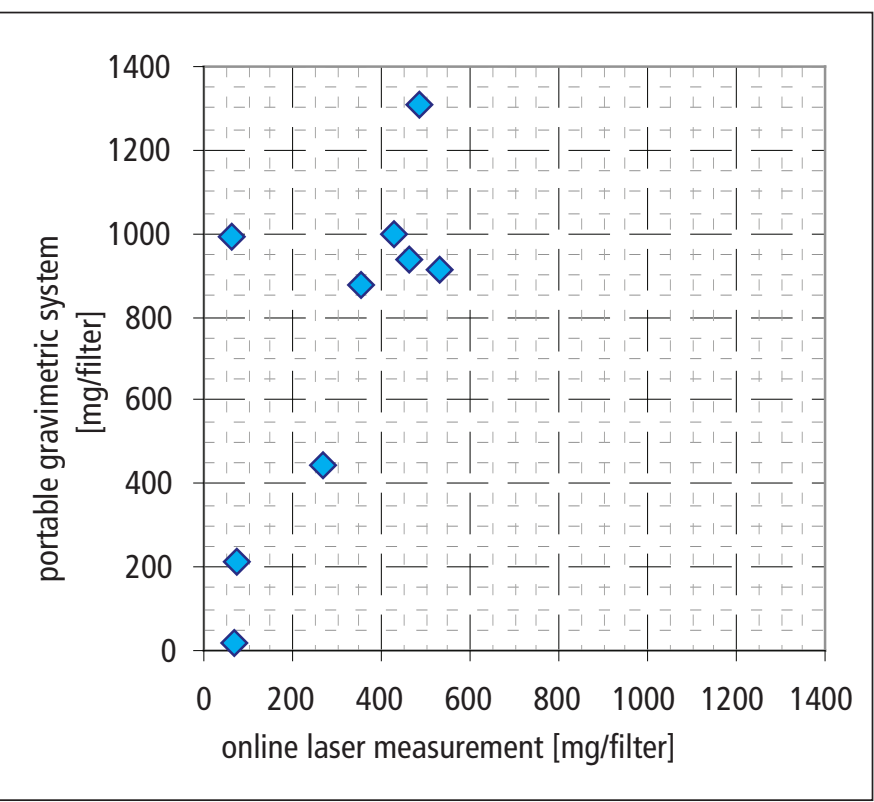

FIGURE 6: PM mass accumulated during a diesel rail vehicle tests on the filters used by the experimental sampling system as inferred by laserbased measurement and as weighted.

OBRÁZEK 6: Hmotnostní emise částic z motorového drážního vozu řady 854 během běžného provozu. Porovnání navážky částic na filtru navzorkvaném experimentálním zařízením (svislá osa) s hypotetickou navážkou (vodorovná osa) vypočtenou jako suma součinů okamžité hmotnostní koncentrace částic měřené rozptylem laserového paprsku a prítoku surových výfukových plynů do vzorkovacího zaříhení.

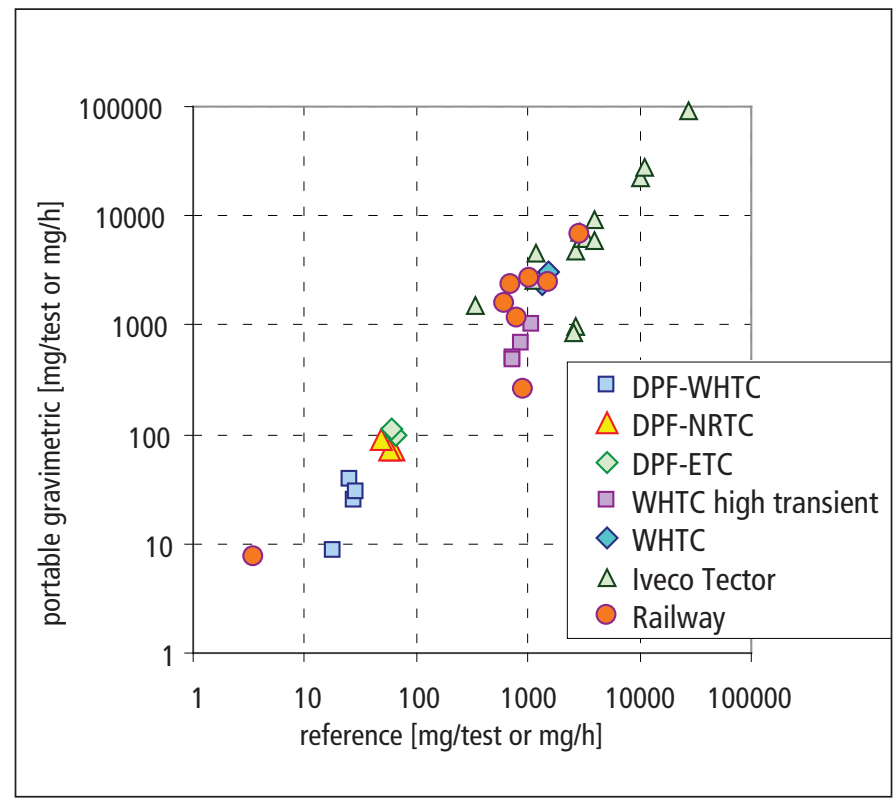

FIGURE 7: Comparison of the PM mass emissions measured by the experimental system (vertical axis) against the respective reference measurements for all tests described here.

OBRÁZEK 7: Hmotnostní emise částic při všech popsaných zkouškách vypočtené na základě měření přenosným vzorkovacím zařízením (svislá osa) a referenční metodou (vodorovná osa). 


\section{DISCUSSION}

The slope of all comparisons appears to be non-unity and shows that the portable system measurements are about twice as high as the reference system, with substantial variability. This deviation appears to hold regardless of the filter material, reference system, drive cycle, or engine emissions characteristics. The source of this discrepancy has not been clearly identified.

One possible source of difference could be a MFC bias. Theoretically, at the declared $1 \%$ of the 50 standard liters per minute (slpm) range MFC accuracy, the maximum deviation of the raw exhaust flow is $2 \times 1 \% \times 50 \mathrm{slpm}=1 \mathrm{slpm}$. At 30 standard liters per minute (slpm) diluted flow rate and the dilution ratio of approximately 5:1 at full load and 30:1 at idle, the maximum raw exhaust sampling rate error corresponds to the desired raw exhaust sampling rate at idle. Empirical fit of the rail vehicle data shows that unity slope between the experimental sampling system and the reference measurement is obtained when a discrepancy of approximately $1 \mathrm{slpm}$ is considered, that is, with both MFC set to equal flows, the system samples approximately $1 \mathrm{slpm}$ of raw exhaust. MFC accuracy, and namely, match between both MFC, is therefore an important limiting factor.

In aspects other than the non-unity slope, the quality of the correlation between the measurement by the portable system and reference measurements is subject to a discussion. Clearly, there is a correlation spanning four orders of magnitude representing various engine technologies and operating modes. At post-DPF levels, the reference measurement is no longer of absolute accuracy, and the correlation is at par with correlation among various traditional laboratory systems [12]. Differences were, however, observed also during operation without a DPF.

One possible source of difference could be a different retention rate of volatile compounds between the systems. For some filters sampled with the portable system, filter weighing records show a decrease of filter mass over time, a sign of accumulation of volatile matter which slowly evaporates over time, often over days and sometimes weeks. This explanation is also consistent with mass emissions measured by the portable system being higher relative to the reference. The transformation of volatile matter to PM can be reduced by increasing dilution ratios, however, due to the exhaust sample flow rate being controlled as the difference of dilution air and diluted sample flows, 5:1 to $10: 1$ at rated power represents a limit beyond which the raw exhaust flow into the sample is difficult to effectively control. Another possible source of error is the contact of the portable system sample filters with a sealing o-ring, the use of which has been later discontinued to resolve this problem. Another source of error is the repeatability of filter mass measurement, which has been brought to units of micrograms, but occasionally has fluctuated over tens of micrograms. It is believed that the implementation of good filter weighing practices, such as close control of temperature and humidity and installation of a static charge neutralizer, can improve the filter weighing accuracy and repeatability. Yet another source of error is the response time of the system. This is a known problem even with commercial laboratory-grade proportional sampling systems [12], and could be more pronounced with the system tested, which was designed for low cost and high portability. Highest PM concentrations tend to be, however, during accelerations, when the exhaust flow is increasing, and slow response would result in lower than desired flow of exhaust into the sample, and thus under-reporting of PM emissions.

Matching the two MFC, heating of the dilution tunnel, proper filter conditioning and weighing procedures, and other described issues have been or are currently being resolved, with the understanding that at some point, practical limits of a small, low-cost system (the experimental system is a fraction of the size and cost of commercial proportional sampling systems) will be reached. The acceptability of the accuracy depends on the context and goals of the measurement; in many cases, notably during field measurement, the accuracy might be sufficient. This is especially the case where installation of a high accuracy system is not plausible from technical or economical reasons.

\section{CONCLUSION}

The performance of an experimental low-cost, portable proportional exhaust sampling system for collection of a sample of particulate matter in exhaust gases from internal combustion engines has been evaluated under transient operation of several compression ignition engines of varying emission levels. Testing was done on engine dynamometers at three laboratories using ETC, WHTC and NRTC test cycles, and on a diesel-powered rail vehicle. Preliminary results from the initial testing appear to be promising, with room for improvement. As with all portable and low-cost systems, accuracy must be weighed against other design parameters. 


\section{ACKNOWLEDGEMENT}

The preparation of this manuscript by the first author was sponsored by the Czech Technological Agency project no. TE01020020 Josef Božek Competence Centre for Automotive Industry and by Support of Research Teams at Czech Technical University in Prague, EU-EBRD, OP VK CZ.1.07/2.3.00/30.0034. The comparison tests took place with the contribution of the first mentioned project, of the Czech Ministry of Education project ED2.1.00/03.0125 (Josef Bozek Vehicle Centre for Sustainable Mobility), and of the EU LIFE+ project LIFE10 ENV/ CZ/651 MEDETOX (Innovative Methods of Monitoring of Diesel Engine Exhaust Toxicity in Real Urban Traffic). The work of the second author was sponsored by the project MEDETOX.

\section{REFERENCES}

[1] Kittelson D.B., 1998. Engines and Nanoparticles. A review. Journal of Aerosol Science, 29, 575-588.

[2] Kittelson D. B., Watts W. F., Johnson, J. P., 2006. On-road and Laboratory Evaluation of Combustion Aerosols Part 1: Summary of Diesel Engine Results. Journal of Aerosol Science 37, 913-930.

[3] Gerde P., Muggenburg, B.A., Lundborg, M., Dahl, A.R., 2001. The rapid alveolar absorption of diesel soot-adsorbed benzo(a)pyrene: bioavailability, metabolism and dosimetry of an inhaled particleborne carcinogen, Carcinogenesis 22, 741 - 749.

[4] Gehr P., Blank F., Rothen-Rutishauser B., 2006. Fate of inhaled particles after interaction with the lung surface. Paediatric Respiratory Reviews 7, Suppl. 1, S73-S75.

[5] Künzli, N, R Kaiser, R, Medina, S, Studnicka, M., Chanel, O., Filliger, P., Herry, M., Horak, F., Puybonnieux-Texier, V., Quénel, P., Schneider, J., Seethaler, R., Vergnaud, J.-C., Sommer, H., 2000. Public-health impact of outdoor and traffic-related air pollution: a European assessment, The Lancet 356, 895- 901 .

[6] Balmes J.R., Earnest G., Katz P.P., Yelin E.H., Eisner M.D., Chem H., Trupin L., Lurmann F., Blanc P.D., 2009. Exposure to traffic: Lung function and health status in adults with asthma. Journal of Allergy and Clinical Immunology 123, 3, 626-631.

[7] Lewtas J., 2007. Air pollution combustion emissions: Characterization of causative agents and mechanisms associated with cancer, reproductive, and cardiovascular effects. Mutation Research 636, 95-133.

[8] McEntee J.C., Ogneva-Himmelberger Y., 2008.

Diesel particulate matter, lung cancer, and asthma incidences along major traffic corridors in MA, USA: A GIS analysis. Health \& Place 14, 817-828.

[9] Gotfrýd, 0., 2012. Adding Transient Cycle Capabilities to an Existing Engine Test Bench. Society of Automotive Engineers, Technical Paper 2012-01-1701.

[10] Voráček, M.: Truck engine operating conditions in heavy Traffic. Bachelor's thesis work, Department of Mechanical Engineering, Technical University of Liberec, Czech Republic, 2013.

[11] Vojtíšek-Lom, M., Cobb, J.T.: On-road light-duty vehicle emission measurements using a novel inexpensive on-board portable system. Sborník konference $8^{\text {th }}$ CRC On-road vehicle emissions workshop, San Diego, California, USA, 1998.

[12] Andersson, J.; Mamakos, A.; Martini, G., 2010: Particle Measurement Programme (PMP) Heavy-duty Interlaboratory Correlation Exercise (ILCE_HD) Final Report. http://www.unece.org.unecedev.colo.iway.ch/ fileadmin/DAM/trans/doc/2009/wp29grpe/PMP-2402e.pdf 